\title{
Augustine's ecclesiology and its development between 354 and 387 AD
}

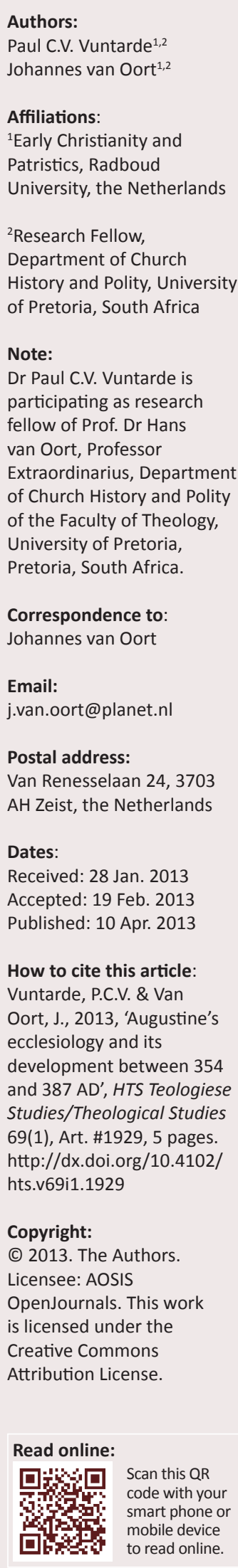

The aim of this article is twofold. The first is to describe Augustine's ecclesiology and its development between his birth (354) and baptism (387). Secondly, it will show that the defining features of Augustine's later ecclesiology were in place by the year 387 AD.

\section{Augustine's ecclesiology between his birth and 19th year (354-373)}

Some scholars like Clark believe that Augustine's ecclesiology was influenced by the preceding African theologians Cyprian, Optatus and his own reading of scripture (1994:73). This seems to be true, but is not the full truth. O'Meara rightly argues that 'men have often forgotten the[se] first years of Christian belief and piety when Augustine was a willing pupil at his mother's knee' (1954:38). Van Oort goes further by saying, that from his early youth, Augustine grew up in the tradition of the Catholic Church and received a Christian education ([1991] 2013:26). It is clear that Augustine did have some form of ecclesiology during this early period of his life yet this is admittedly difficult to fully determine. Nonetheless, there is evidence to show its existence and that Augustine remembered what it was when he penned the Confessions.

The clearest evidence for this is Augustine's recollection of his childhood experience in Book 1 of the Confessions: 'While still a boy I heard about eternal life promised through the humility of our Lord and God' (Confessionum libri XIII 1.17 in Boulding 1998:50; see Van Oort [1991] 2013:26). He continues to say 'I pleaded with my loving mother and with the mother of us all, your Church' for this eternal life (Confessionum libri XIII1.17 in Boulding 1998:50-51; see Van Oort [1991] 2013:26).

These statements make one realise that, somehow, Augustine had learnt about salvation and that the Church was in some way the custodian of this promised eternal salvation. He would have thus been acquainted at the very least with these two ecclesiological ideas.

A third ecclesial idea he would have been familiar with at this stage is that of baptism. Augustine would have been pleading for a deathbed baptism when he fell ill (Confessionum libri XIII 1.11, 17 in Boulding 1998:50-51). This also means that Augustine would have known, at least in part, that the baptismal rite was the initiatory rite of the Catholic Church - it was the act of bestowing salvation on an individual.

The next logical question would be: What type of ecclesiology did Augustine learn? Augustine was influenced by Monnica, by the Catholic Church in Roman North Africa and by other Christians. He would have learnt Catholic ecclesiology. One can conclude that the nature of his ecclesial thinking would have been Catholic in content, extent and depth.

Perhaps someone might argue that Thagaste was a Donatist city and thus Augustine would have been influenced by Donatist ecclesiology as well. Thagaste, the city in which Augustine grew up, seems to have been a Donatist city at some point. However, the people of Thagaste converted fully to Catholicism before Augustine's birth (Fitzgerald 2009:37).

Furthermore, there was very little difference in the ecclesiology of the Catholics and Donatists (Markus 1999:286). So whichever influence he received most, Augustine would have had much in common with the opposing party.

How deep was Augustine's Catholic ecclesiology at this point in his life? Augustine's ecclesial thoughts before the age of 19 years (354-373) were most likely very shallow in depth and content. What evidence is there for this kind of thinking? Firstly, though Augustine was a catechumen, Boulding (1998:50) makes it clear that Augustine would not have received any formal systematic Christian instruction at this stage. Perhaps it was left up to the parents to instruct their children 
in the way they should go. Nonetheless, not much can be expected of Augustine's ecclesiology at this first stage of his catechetical instruction.

Secondly, Augustine seems to have studied scripture only when he was in Carthage 'to find out what they were like' compared to Cicero (Confessionum libri XIII 3.9 in Boulding 1998:80). This would make it very unlikely that Augustine's ecclesiology was deep since he had not personally studied the Church's foundational source documents on ecclesial thoughts.

Thirdly, Augustine was still a young man. He seemed less interested in Church matters. In Confessionum libri XIII 3.5 (in Boulding 1998) Augustine testifies:

How great were the sins on which I spent all my strength, as I followed my impious curiosity! It led me to abandon you and plunge into treacherous abysses, into depths of unbelief (p. 78).

Though Augustine still received some Catholic Christian instruction (Van Oort [1991] 2013:26; Confessionum libri XIII 3.5 in Boulding 1998), it seems that Augustine's ecclesiology was shallow at best or even receding as he abandoned the faith of his youth.

\section{Augustine ecclesiology between his 19 th and 28th years of age}

Between 373 and 382 AD, Augustine was involved with a group known as the Manichaeans (Ferguson 2005:269; cf. Frend 1984:662). Due to many recent discoveries, it has become clear that these Manichaeans were not some Zoroastrian-influenced people subscribing to dualist convictions, but a real variety of early Christians; they even considered themselves to be the 'true Christians' and their community the true 'Church' (Van Oort 2009). During this Manichaean period Augustine's ecclesiology grew in line with the Manichaean ecclesiology he embraced. Some scholars like Coyle (2007:184) argue that Augustine, as an auditor, would not have had access to all of Mani's teachings and hence his knowledge of the doctrines would be considerably incomplete.

Is it possible that such an inquisitive mind as Augustine's would have for nine years followed a religious system blindly? A careful reader of the Confessions might come to a very different conclusion for the following three reasons:

Firstly, Augustine says:

O truth, truth, how the deepest and innermost marrow of my mind ached for you, even then while they prattled your name to me unremittingly and in so many ways, though only in words and in their huge and copious tomes! (Confessionum libri XIII 3.10 in Boulding 1998:81)

Augustine seems to be saying that he came to know what the Manichaeans taught through words (probably a reference to audible instruction) and 'their huge tomes' - their books. This is further strengthened by Confessionum libri XIII 5.12: Augustine, referring to Manichaean teachings, states that 'their books are full of interminable myths' (Boulding 1998:121).

Augustine clearly distinguished between what he observed in their books as well as in philosophical books; we can therefore infer that he had some sort of access to them.

Secondly, Augustine notes how he compared the calculations of the astronomers 'with the assertions of Mani, who had written voluminously (and incoherently) on these subjects' (Confessionum libri XIII 5.6 in Boulding 1998:117). Just the fact that he mentions this means he must have had some form of access to Mani's works. He continues to say that what he:

read there was confirmed neither by any rational account of solstices and equinoxes and eclipses, nor by anything else of this kind that I had learned from books of secular philosophy [which further strengths the fact that he had read the Manichaean works]. (Confessionum libri XIII5.6 in Boulding 1998:117)

Thirdly, Van Oort states that 'Augustine, already as a hearer ... became thoroughly acquainted with the teachings of the Manichaean Church and that he even read their writings' (Van Oort [1991] 2013:45). He uses as one of his evidences Confessionum libri XIII 3.21 (Van Oort [1991] 2013:45). In that portion of the Confessions, Augustine speaks of a certain bishop who attempts to comfort Monnica by claiming Augustine would himself read from the Manichaean teachings (Van Oort [1991] 2013:45) - 'he will find out for himself through his reading how wrong these beliefs are, and how profoundly irrelevant' (Confessionum libri XIII 3.21 in Boulding 1998:90). The question now is: what kind of reading would lead him away from the Manichaean beliefs? It might refer to the study of philosophy, scripture or the Manichaean teaching itself. One need only read further and the veil is lifted when the bishop says:

he had himself been handed over to the Manichees as a little boy by his mother, who had been led astray; he had not only nearly read all their books but had even written some himself. (Confessionum libri XIII 3.21 in Boulding 1998:91)

The bishop clearly draws a parallel between his experience and Augustine's. He aims to show that just as he, through his reading moved away from the Manichaean teachings, Augustine would do likewise. The books he read, he identifies as being the Manichaean books (Confessionum libri XIII 3.21 in Boulding 1998:91). This means that Augustine would do likewise and through his reading, move away from the Manichaean books (Van Oort 2004:35-37).

Furthermore, in The Catholic Way of Life and The Manichaean Way of Life, Augustine says that he is not lacking in knowledge of the Manichaean way of thinking (De moribus ecclesiae catholicae 1.30 in Teske 2006:45). This suggests that he speaks from a point of researched authority and not just out of ignorance to the Manichaean way of life.

This leads one to conclude that as a result of the Manichean influence, Augustine's ecclesiology grew in depth as well as content. He adopted Manichaean ecclesiology. The Manicheans presented themselves as following a more 
rational kind of Christianity (O'Meara 2001:68). He would have read the works of Paul and their own Manichaean writings from such a conceptual perspective. A likely summary of Augustine's ecclesiology at this point would have been the following:

1. Superiority of the Manichaean Church over the Catholic Church.

2. One enters the Church through Gnosis - the knowledge of light and darkness (Coyle 2007:182; Frend 1984:315).

3. There are two types of believers in the Church, the elect and the hearers.

4. Hearers may be saved by their meritorious works for the elect (Coyle 2007:182).

5. The Church's mission is to release light particles held captive in the intermingled darkness and light of creation (Coyle 2007:182; Frend 1984:662).

6. The Elect are arranged in a hierarchy (Coyle 2007:183).

7. How the Church is to go about proselytising (Van Oort [1991] 2013:44)

8. Some New Testament ecclesial teachings.

9. Ecclesial nuances in the cultic and ethical code of Manichaeism.

10. Some Pauline ecclesiology. How much? There is no way we can exactly know; although Augustine's ecclesiological ideas might have coincided with those expressed in a Latin Manichaean document such as the Tebessa Codex (BeDuhn \& Harrison 1997).

There are clearly links between this Manichaean phase and Augustine's later ecclesiology. How was Augustine's later ecclesiology influenced by this Manichaean ecclesiology?

Firstly, Augustine wrote many tracts and books against the Manichaeans after his baptism (Van Oort 2009:129). This antithetical approach was necessitated by Manichaeism, and also led Augustine to a conservative approach to the text of the Bible and its translations (see Van Oort 2004:717). This would have bearing on how he interpreted ecclesial passages and hence his own ecclesial formation.

Secondly, there are many similarities in Augustine's later ecclesiology and Manichaean ecclesiology. Van Oort ([1991] 2013:129) argues along these lines and shows that there are similarities between Augustine's 'doctrine of the two "cities" or "kingdoms" (Latin: civitates) and the dualistic Manichaean view of the two "realms", "cities" or "kingdoms".' So there is a coherence and continuity in Augustine's early and later ecclesiology. Coyle rightly says that it is very difficult to imagine Augustine's thought apart from the Manichaean experience through which he lived, to which he reacted and by which he was shaped in many ways' (Coyle 2007:191).

\section{Augustine's ecclesiology between his 29th year and his conversion}

What can one say about Augustine's ecclesiology during this phase? Between the age of 29 and his baptism, Augustine's ecclesiology is marked by uncertainty. At 29 years of age, he had noticed the gaping holes in the logic of the Manichaean teaching. When Faustus could not give him the answers to these issues he was disillusioned (Confessionum libri XIII 5.17 in Boulding 1998:127). At this point Augustine became definitely disenchanted with Manichaeism and his Manichaean ecclesiology stagnated (Confessionum libri XIII 5.18 in Boulding 1998:127).

Augustine only held the beliefs of the Manichaean Church simply because there was nothing better in his estimations (Confessionum libri XIII 5.13 in Boulding 1998:122). Since he also found it of great advantage to believe that his sin was not his fault but merely some other nature within him that was responsible, he in part continued to cling to Manichaean teachings (Confessionum libri XIII 5.18 in Boulding 1998:126). He then became a doubter of everything, aligning himself with the Academics (Confessionum libri XIII 5.24 in Boulding 1998:132). This would have included doubt in the ecclesial teachings he had obtained.

Augustine then settled again within the Catholic Church as a catechumen (Confessionum libri XIII 5.25 in Boulding 1998:133). He merely did this until he was sure about which course to take in his pursuit of wisdom (Confessionum libri XIII 5.25 in Boulding 1997:133).

Seeing as Augustine's pursuit for truth governed his ecclesiology, it becomes unclear, yet again, what his specific ecclesiology was at this point. What is clear though is that the teachings of the Catholic Church began to make their way into his mind as he came under the influence of their liturgy, readings and sermons (Confessionum libri XIII 4.5 in Boulding 1998:139).

Augustine would have been influenced especially by the Pauline writings as he began to re-read them through a Catholic lens (Confessionum libri XIII 21.27 in Boulding 1998:181). There is one area in Augustine's ecclesial thinking that is clearly portrayed in a story within the Confessions. This story welled up a sense of passionate desire in Augustine to do likewise: he desired to imitate Victorinus. This tells us that Augustine had come to believe to some extent, that it is through the Catholic Church, that one is born into Christ's Church and not simply by reading the scriptures (Confessionum libri XIII 8.10 in Boulding 1998:192). This was reflected earlier in Confessionum libri XIII 6.4 where he says, 'Christians who are reborn in their mother the Church' (Mara 2007:205). It also means that Augustine had begun to accept that reason was not above authority as the Manichaean Church thought. He was now eager to receive this promised salvation by the Church's authority.

Apart from this it is difficult to define the extent of Augustine's ecclesiology. Augustine was then converted to Catholic Christianity in August 386 AD and soon afterward retreated to Cassisiacum (Alexander 2008:59).

\section{Augustine's ecclesiology between his conversion and his baptism}

After his conversion to Catholic Christianity in Milan, Augustine went and stayed at Cassisiacum with a group that 
included his mother, his brother, his son, some friends and two students. He spent a total of six months there awaiting baptism (Boulding 1998:219). It is here that we see Augustine write his first post-conversion works (Lancel 1999:102). These books cast an interesting light on Augustine's state of mind after he had just been converted to Catholic Christianity (Dudden 1935:335). These books are also known as the Cassiciacum Dialogues (Alexander 2008:30). They are namely, Answer to the Skeptics (Contra Academicos), The Happy life (De vita beata), Divine Providence and the Problem of Evil (De ordine), and the two books of the Soliloquia (O'Meara 2001:196; cf. Alexander 2008:30).

Augustine goes to Cassisiacum in northern Italy, not far from the city of Milan, with a group of friends and family. They attempt to make sense of their new-found faith in their own distinctive education and cultural formation (Harrison 2007:166). The following are insights from Augustine's ecclesiology, found in the Dialogues at Cassisiacum:

1. Baptism is a salvific initiatory rite (Augustine 1948c:66, De vita beata 3.18; see Confessionum libri XIII 1.17 in Boulding 1998:50-51).

2. Exorcism is a rite performed during such baptisms (Augustine 1948c:66, De vita beata 3.18).

3. There is a hierarchical Church government structure within the Church (Augustine 1948c:66, De vita beata 3.18; see Harmless 1995:94).

4. Scripture and Catholic Church tradition are authoritative in matters of faith and practice of the Church (Augustine 1948c:83, De vita beata 4.35; see Alexander 2008:44).

5. The Catholic Church is Christ's body (Alexander 2008:44; cf. Augustine1948a:219).

6. Christ is the head of the Church - When Augustine later encounters the Donatists, his response has its centre around Christ as the head of his body (Bonner 1987:453). Yet again we see that Augustine's future ecclesiology is founded upon his earlier ecclesial understanding.

7. Pauline Ecclesiology - From Contra Academicos, we become aware of the fact that Augustine was in the habit of reading scripture thoroughly and with great attention before he went to Cassisiacum (Alexander 2008:43-45). This concurs with Dudden who notes that Augustine would have meticulously read the Pauline Epistles by this stage (1935:330)

8. Church worship in prayer (Augustine 1948a:135, Contra Academicos 2.2).

9. Christ's philosophy on the Church was the only philosophy to live by (Augustine 1948b:271, De ordine 1.31).

10. Women could also teach men in the Church (Augustine 1948b:270-271, De ordine 1.31).

11. One becomes a part of the Church by faith.

12. In comparison with the world, the Church is in the minority (Augustine 1948d:344-345, Soliloquiorum libri II.1.2)

13. Unity in the Church through love (Augustine 1948d:346, Soliloquiorum libri II.1.3).

14. The Church has a mission to perform.
We see a definite growth in Catholic ecclesiology within Augustine's ecclesial understanding when we carefully investigate his works as to their historical background. Understanding that Augustine had arrived at such an ecclesiology reveals that before he had begun engaging in the Donatist Schism, Augustine had already an ecclesial framework from which he was working. Augustine also learned the allegorical way of looking at scripture. This is very important to note. He used this framework of interpreting scripture in his sermons and letters throughout his life for teaching purposes on ecclesial aspects.

Augustine's ecclesiology grows to an even greater extent between August 386 AD and February 387 AD. During this period Augustine became a competens (someone 'who strives after' baptism), and after that a neophyte (a 'newly born', i.e. a just baptised person). During this period clear ecclesiological teachings in the form of sermons, liturgy and special instruction in Milan flowed from Ambrose's pen. Augustine most likely came to believe the following:

1. The Church is a teacher (Augustine 1988:14, De fide et operibus 6.9; Ambrose 1962b:280, De sacramentis 2.8; see Alexander 2008:137).

2. The Church is made up of a priesthood of believers.

3. The Church is Christ's bride (Ambrose, 1962a:17-20, De mysteriis 7.35-42).

4. The Church is universal (Alexander 2008:134-135; Ambrose 1962b:280, De sacramentis 2.5).

5. Christ baptises in and through the sacraments (Ambrose 1962b:283, De sacramentis 2.9).

6. The significance of baptism as initiated by the Church.

7. The conception of the Church is in the Old Testament with Abel (Van Bavel 1999:169-170).

8. The rite of secrecy of baptism and the Eucharist (Harmless 1999:147).

9. The Church is a mixed body (Alexander 2008:133; Hill 1993:157).

\section{Conclusion}

It has been shown that Augustine's ecclesiology was dynamic and changed throughout his life. Before he was 19 years old he already had rudiments of a Catholic ecclesiology. When he left the Catholic Church for the Manichaeans, Augustine embraced Manichaean ecclesial thinking. Then he went through a period of doubt until he embraced Catholic Christianity and its ecclesial thinking.

As has already been shown throughout this article: Augustine's earlier ecclesial thinking formed a framework for his later ecclesial thinking. When one looks at this early period of Augustine's ecclesial formation, one realises that the defining features of Augustine's later ecclesiology were in place by $387 \mathrm{AD}$. These defining features were Augustine's belief in the authority of the Church as teacher in matters of faith and practice, and the authority of God's Word, which the Catholic Church correctly interprets for faith and practice. Thus the above teachings that have been discussed mirror 
this reality of Augustine's ecclesiology. Moreover, it has been proven that - unlike often stated in popular tales - Augustine before his conversion (386) and baptism (387) was not merely a pagan, but a Christian believer whose ecclesiology already took shape.

\section{Acknowledgements Competing interests}

The authors declare that they have no financial or personal relationship(s) which may have inappropriately influenced them in writing this article.

\section{Authors' contributions}

This article is based on a part of P.C.V.V.'s (University of Pretoria) MA thesis 'Augustine's Ecclesiology and its Development between the Years 354-387 AD', which was supervised by J.v.O. (University of Pretoria) in 2012.

\section{References}

Alexander, D.C., 2008, Augustine's early theology of the Church: emergence and implications 386-391, Peter Lang, New York.

Ambrose, 1962a, 'De mysteriis', in R.J. Deferrari (ed.), Saint Ambrose: theological and dogmatic works, pp. 5-30, Catholic University of America Press, Washington.

Ambrose, 1962b, 'De sacramentis', in R.J. Deferrari (ed.), Saint Ambrose: theological and dogmatic works, pp. 265-328, Catholic University of America Press, Washington.

Augustine, 1948a, 'Contra academicos', in D.J. Kavanagh, 'Answer to Skeptics (Contra Academicos)', in L. Schopp (ed.), Writings of Saint Augustine 1, pp. 87-103, CIMA New York.

Augustine, 1948b, 'De ordine', in R.P. Russell, 'Divine providence and the problem of evil (De ordine)', in L. Schopp (ed.), Writings of Saint Augustine 1, pp. 229-239, CIMA, New York.

Augustine, 1948c, 'De vita beata', in L. Schopp (ed.), Writings of Saint Augustine 1, pp. 29-43, CIMA, New York.

Augustine, 1948d, 'Soliloquiorum libri, II', in T.F. Gilligan, 'Soliloquies', in L. Schopp (ed.), Writings of Saint Augustine 1, pp. 335-343, CIMA, New York.

Augustine, 1988, De fide et operibus, in G.J. Lombardo (ed.), St Augustine: on faith and works, n.p., Newman, New York. PMCid:1191765

Augustine, 1997, 'Confessionum libri XIII', transl. M. Boulding, 'The confessions', in J.E. Rotelle (ed.), The works of Saint Augustine in: a translation for the 21st century, pp. 39-380, New City Press, Hyde Park.
Augustine, 2006, 'De moribus ecclesiae catholicae', R. Teske, 'The way of the Catholic Church and the way of the Manichaean Church (De moribus ecclesiae catholicae)', in B. Ramsey (ed.), The works of Saint Augustine: a translation for the 21st century, in B. Ramsey (ed.), The works of Saint A
pp. 17-69, New City Press, Hyde Park.

BeDuhn, J.D. \& Harrison, G., 1997, 'The Tebessa Codex: A Manichaean treatise on Biblical exegesis and Church order', in P.A. Mirecki \& J.D. BeDuhn (eds.), Emerging from darkness: studies in the recovery of Manichaean sources, pp. 33-87, E.J. Brill, Leiden.

Bonner, G., 1987, God's decree and man's destiny, Variorum, London.

Boulding, M., 1998, 'The confessions', in J.E. Rotelle (ed.), The works of Saint Augustine in: A translation for the 21st century, transl. R.J. Teske, pp. 39-380, New City Press, Hyde Park.

Clark, M.T., 1994, Augustine. New York: Georgetown University Press.

Coyle, K.J., 2007, 'The Manichaeism of Augustine', in T.J. van Bavel in collaboration with B. Bruning (eds.), Saint Augustine, pp. 185-211, Mercatorfonds, Brussels.

Dudden, H F., 1935, The life and times of St. Ambrose, Clarendon, Oxford.

Ferguson, E., 2005, Church history: from Christ to Pre-Reformation, Zondervan, Grand Rapids.

Fitzgerald, A.D., 2009, 'When Augustine was priest', Augustinian Studies 40(1), 37-48. http://dx.doi.org/10.5840/augstudies20094014

Frend, W.H.C., 1984, The rise of Christianity, Fort Press, Philadelphia.

Harmless, W., 1995, Augustine and the Catechumenate, Liturgical, Minnesota.

Harmless, W., 1999, s.v., 'Catechumens, catechumenate', in A.D. Fitzgerald (ed.), Augustine through the ages: An encyclopaedia, Eerdmans, Grand Rapids, pp. 145-149.

Harrison, C., 2007, 'The early works', in T.J. van Bavel in collaboration with B. Bruning (eds.), Saint Augustine, pp. 165-179, Mercatorfonds, Brussels.

Hill, E., 1993, 'Sermon 214', in J.E. Rotelle (ed.), The works of Saint Augustine: a translation for the 21st century, pp. 150-159, New City Press, New York. PMid:8435005, PMCid:1029208

Lancel, S., 1999, Saint Augustine, SCM, London.

Mara, M., 2007, 'Augustine and the Church', in T.J. van Bavel in collaboration with B. Bruning (eds.), Saint Augustine, pp. 185-211, Mercatorfonds, Brussels.

Markus, R.A., 1999, s.v., 'Donatus, Donatism', in A.D. Fitzgerald (ed.), Augustine through the ages: An encyclopaedia, Eerdmans, Grand Rapids, pp. 284-287.

O'Meara, J.J., 1954, The young Augustine: an introduction to the Confessions of Saint Augustine, Longman, London.

O'Meara, J.J., 2001, The young Augustine: the growth of Saint Augustine's mind up to his conversion, Alba House, New York.

Van Bavel, T.J., 1999, s.v., 'Church', in A.D. Fitzgerald (ed.), Augustine through the ages: An encyclopaedia, Eerdmans, Grand Rapids, pp. 169-175.

Van Oort, J., 2004, 'Augustine and Manichaeism in Roman North Africa', in E.H. Raidt (ed.), Augustine Papers 1 (no. 2), pp. 32-51, Saint Augustine College of South Africa, Johannesburg.

Van Oort, J., 2009, 'Manichaeism: Its sources and influences on Western Christianity', Verbum et Ecclesia 30(2), Art. \#362, 5 pages. http://dx.doi.org/10.4102/ ve.v30i2.362

Van Oort, J., [1991] 2013, Jerusalem and Babylon: a study into Augustine's City of God and the sources of his doctrine of the Two Cities, E.J. Brill, Leiden. 